\title{
INTENSITAS MIELUM PADA GAMBARAN MRI SERVIKAL SEBAGAI FAKTOR PROGNOSTIK LUARAN CERVICAL SPONDYLOSIS MYELOPATHY PASCAOPERASI
}

\author{
MYELUM INTENSITY ON MRI CERVICAL AS PROGNOSTIC FACTORS IN \\ CERVICAL SPONDYLOSIS MYELOPATHY PATIENTS
}

\begin{abstract}
Mohamad Saekhu, * Jeremia Prastya Pardede, * Renindra Ananda Aman, * Hanif Gordang Tobing, Samsul Ashari, * David Tandian, * Syaiful Ichwan, * Wismaji sadewo, * Affan Priyambodo, * Setyo Widi Nugroho*
\end{abstract}

\section{ABSTRACT}

Introduction: Cervical spondylosis myelopathy (CSM) is a stenosis condition in cervical canal due to the cervical structural changes that compress the myelum, thus causing spinal medulla ischemia. Other than clinical factors, myelum intensity changes on MRI T1-weighted images (T1W1) and T2W1 might be useful to predict the pos-operative outcome.

Aims: Identify prognostic factors in post-operative patients with CSM based on clinical symptoms and myelum intensity on cervical MRI.

Methods: Retrospective study on CSM patients who underwent surgery in Neurosurgery Department, Cipto Mangunkusumo hospital, Jakarta, from January 2013 to December 2016. Magnetic resonance imaging data was obtained before the surgery, while clinical symptoms were assessed by Nurick scale before and 1 year after the surgery to evaluate outcome.

Results: There were 50 subjects included in this study with mean age 51.98 9.64 years, majority male (76\%), have moderate myelopathy (Nurick scale pre-operative $\leq 2$ ), and time between onset and surgery mostly $\leq 1$ year (80\%). Most subject (88\%) had improvement clinically, but mostly without hypointensity on cervical TIWI MRI.

Discussion: Myelum hypointensity in cervical MRI is associated with poor outcome in CSM post-surgery patients.

Keywords: Cervical spondylosis myelopathy, MRI, myelum hypointensity, Nurick scale

\section{ABSTRAK}

Pendahuluan: Cervical spondylosis myelopathy (CSM) merupakan suatu kondisi stenosis kanal servikal akibat adanya perubahan struktur servikal yang menyebabkan kompresi mielum, sehingga timbul iskemia medula spinalis. Selain faktor-faktor klinis, perubahan intensitas mielum pada MRI T1-weighted images (T1W1) dan T2W1 dapat dijadikan modalitas untuk memprediksi luaran pascaoperasi.

Tujuan: Mengidentifikasi faktor prognosis luaran pasien CSM pascaoperasi berdasarkan gejala klinis dan intensitas mielum pada gambaran MRI servikal.

Metode: Penelitian retrospektif terhadap penderita CSM yang dilakukan operasi di Departemen Bedah Saraf RSUPN Dr. Cipto Mangunkusumo, Jakarta, pada bulan Januari 2013 hingga Desember 2016. Dilakukan penilaian klinis dan gambaran MRI awal, serta luaran 1 tahun pascaoperasi menggunakan skor Nurick.

Hasil: Terdapat 50 subjek dengan rerata usia 51,98 $\pm 9,64$ tahun, terutama laki-laki (76\%), memiliki derajat mielopati ringan (skor Nurick preoperasi $\leq 2$ ), dan jarak antara onset dengan waktu operasi $\leq 1$ tahun $(80 \%)$. Sebagian besar subjek (88\%) mengalami perbaikan skor pascaoperasi yang mayoritas $(95,4 \%)$ tidak didapatkan gambaran hipointesintas pada T1W1 MRI servikal.

Diskusi: Hipointensitas mielum pada MRI servikal merupakan faktor prognosis luaran buruk pascaoperasi pada pasien CSM.

Kata kunci: Cervical spondylosis myelopathy, hipointens, mielum, MRI, skala Nurick

*Departemen Bedah Saraf FK Universitas Indonesia/RSUPN Dr. Cipto Mangunkusumo, Jakarta. Korespondensi: dr.jeremia@gmail.com.

\section{PENDAHULUAN}

Cervical spondylosis myelopathy (CSM) didefinisikan sebagai suatu kondisi stenosis kanal servikal akibat adanya perubahan struktur servikal yang umumnya disebabkan oleh proses degeneratif atau osifikasi ligamentum longitudinal posterior (OPLL). Hal ini akan mengakibatkan terjadinya kompresi mielum, sehingga timbul iskemia medula spinalis. Cervical spondylosis myelopathy merupakan penyakit yang bersifat kronik progresif dan dapat menyebabkan morbiditas klinis yang signifikan, terutama pada pasien usia $>50$ tahun. Gejala pada CSM dapat bersifat asimtomatik, sehingga onset gejala biasanya tersembunyi, yang diikuti dengan 
episode perburukan gejala. Penekanan kronik pada medula spinalis dapat menyebabkan penurunan kualitas hidup dan kerusakan neurologis yang ireversibel. ${ }^{1-2}$

Terdapat berbagai faktor yang dilaporkan dapat memengaruhi luaran pascaoperasi pasien CSM, antara lain usia, jarak waktu antara awitan dengan tindakan operasi, serta gambaran MRI. Usia merupakan faktor prediktor yang independen; pertambahan usia menyebabkan perubahan degeneratif pada struktur servikal serta berkurangnya serabut mielin pada traktus kortikospinal dan posterior funikulus. Adapun jarak antara awitan gejala hingga waktu operasi yang berkisar antara 12 sampai 18 bulan diprediksi memiliki prognosis yang rendah. ${ }^{3-4}$

Perubahan intensitas mielum pada MRI T1weighted images (T1W1) dan T2W1 dapat dijadikan modalitas untuk memprediksi luaran pascaoperasi. Perubahan intensitas ini merupakan akibat dari perubahan tissue relaxation (TR). Semakin berat derajat kerusakan mielum, maka akan semakin tinggi kandungan air di dalam mielum. Hal ini mengakibatkan peningkatan TR dan memberikan gambaran hipointens di T1WI dan hiperintens di T2WI. Peningkatan intensitas (hiperintens) mielum pada MRI T2WI menunjukkan edema dan gliosis yang masih mungkin reversibel, sedangkan perubahan sinyal rendah (hipointens) pada T1WI menunjukkan mielomalasia dan nekrosis yang bersifat ireversibel. Namun masih terdapat relasi yang inkonsisten antara gejala klinis dengan temuan radiologi tersebut. ${ }^{5-7}$

Sejauh ini belum ada faktor prognosis luaran pasien CSM di Indonesia yang dapat dijadikan sebagai acuan tindakan operasi dekompresi kanal servikal. Nurick grading system merupakan salah satu skala yang digunakan untuk menilai berat ringan kondisi mielopati terutama pada penilaian awal di rawat jalan. Skor ini dapat melihat pengaruh CSM terhadap pekerjaan dan aktivitas pasien. ${ }^{8}$

\section{TUJUAN}

Mengetahui faktor prognostik yang memiliki pengaruh terhadap luaran pascaoperasi pada CSM berdasarkan gejala klinis dan intensitas mielum pada gambaran MRI servikal.

\section{METODE}

Penelitian retrospektif terhadap penderita CSM yang dilakukan operasi di Departemen Bedah Saraf
RSUPN Dr. Cipto Mangunkusumo, Jakarta, dalam periode Januari 2013 hingga Desember 2016. Kriteria inklusi meliputi pasien dengan keluhan mielopati akibat proses spondilosis, hipertrofi ligamentum flavum, OPLL, herniasi diskus, subluksasi atau kombinasi akibat perubahan proses degeneratif yang ditegakkan berdasarkan temuan gejala klinis, pemeriksaan fisik, serta temuan pada MRI. Kriteria eksklusi adalah riwayat operasi tulang belakang leher sebelumnya.

Dilakukan pengambilan data demografi, skor fungsional Nurick preoperasi, jarak antara onset dengan waktu operasi, jenis tindakan pembedahan, serta temuan intensitas mielum MRI servikal preoperasi. Skor Nurick preoperasi dikelompokkan berdasarkan beratnya mielopati yang sampai mengganggu aktivitas, yaitu menjadi $\leq 2$ (ringan) dan $>2$ (berat). Pemeriksaan MRI menggunakan alat MRI Siemens Avanto 1,5 Tesla untuk menilai perubahan intensitas mielum pada sekuens T1WI nonkontras dan T2WI potongan sagital yang dilakukan $<6$ bulan sebelum waktu operasi yang dibaca oleh tim neuroradiologi RSUPN Dr. Cipto Mangunkusumo.

Penelitian ini telah mendapat persetujuan dari Komite Etik Penelitian Kesehatan Fakultas Kedokteran Universitas Indonesia dengan nomor 924/UN2.F1/ETIK/2017. Data diolah menggunakan program SPSS. Dilakukan analisis bivariat menggunakan uji Chi-square, dan jika syarat tidak terpenuhi, digunakan Fisher test. Luaran pascaoperasi dinilai dengan menghitung perbedaan antara skor fungsional Nurick preoperasi dan 1 tahun pascaoperasi, dikatakan terdapat perbaikan jika subjek mendapatkan skor yang lebih kecil.

\section{HASIL}

Didapatkan 50 subjek dengan rerata usia $51,98 \pm 9,64$ tahun. Mayoritas subjek adalah lakilaki (76\%), memiliki derajat mielopati ringan yang belum mengganggu aktivitas (skor Nurick preoperasi $\leq 2$ ) sebanyak $62 \%$, jarak antara onset dengan waktu operasi $\leq 1$ tahun ( $80 \%$ ), dan tindakan yang dikerjakan adalah prosedur anterior (76\%). Dari gambaran MRI, didapati $10 \%$ subjek memiliki gambaran mielum hipointens pada T1WI dan $40 \%$ memiliki gambaran hiperintens, seluruh pasien dengan hipointensitas 
mielum di T1WI memiliki gambaran T2WI yang hiperintens juga (Tabel 1). Sebanyak 88\% subjek mengalami perbaikan skor fungsional Nurick.

Tabel 1. Karakteristik Subjek $(n=50)$

\begin{tabular}{|c|c|}
\hline Variabel & n (\%) \\
\hline \multicolumn{2}{|l|}{ Usia } \\
\hline • $\leq 65$ & $47(94)$ \\
\hline - $>65$ & $3(6)$ \\
\hline \multicolumn{2}{|l|}{ Jenis kelamin } \\
\hline - Laki-laki & $38(76)$ \\
\hline - Perempuan & $12(24)$ \\
\hline \multicolumn{2}{|l|}{ Nurick preoperasi } \\
\hline - $\leq 2$ & $31(62)$ \\
\hline$\bullet>2$ & $19(38)$ \\
\hline \multicolumn{2}{|c|}{$\begin{array}{l}\text { Jarak antara onset dengan waktu } \\
\text { operasi }\end{array}$} \\
\hline - $\leq 1$ tahun & $40(80)$ \\
\hline - $>1$ tahun & $10(20)$ \\
\hline \multicolumn{2}{|l|}{ Tindakan } \\
\hline - Anterior & $38(76)$ \\
\hline - Posterior & $12(24)$ \\
\hline \multicolumn{2}{|c|}{ Hipointensitas pada MRI T1WI } \\
\hline - Ada & $5(10)$ \\
\hline - Tidak ada & $45(90)$ \\
\hline \multicolumn{2}{|c|}{ Hiperintensitas pada MRI T2WI } \\
\hline - Ada & $20(40)$ \\
\hline - Tidak ada & $30(60)$ \\
\hline \multicolumn{2}{|l|}{ Perubahan skor Nurick } \\
\hline - Perbaikan & $44(88)$ \\
\hline - Tidak & $6(12)$ \\
\hline
\end{tabular}

MRI: magnetic resonance imaging; T1WI: T1-weighted images;

T2WI: T2-weighted images.

Walaupun tidak bermakna, usia $>65$ tahun tidak ada yang mengalami perbaikan luaran pascaoperasi (Tabel 2). Adapun dari semua subjek yang mengalami perbaikan gejala, mayoritas $(95,4 \%)$ tidak didapatkan gambaran hipointesintas pada T1W1 $(\mathrm{p}=0,009)$.

\section{PEMBAHASAN}

Mayoritas subjek adalah laki-laki (76\%), sesuai dengan literatur bahwa kasus CSM terbanyak pada pasien usia tua dan laki-laki, dengan kisaran rasio 2:1. Secara umum laki-laki memiliki aktivitas lebih tinggi, dan hal tersebut erat kaitannya dengan faktor statis dan dinamis pada patofiologi CSM. ${ }^{9}$
Pada penelitian ini, pertimbangan pemilihan usia 65 tahun berdasarkan survei AOSpine International yang mengkategorikan usia 65 tahun sebagai usia tua (elderly) dan sebagai ambang usia yang mengalami dampak negatif paling signifikan pascapembedahan pada pasien dengan CSM. Usia $>65$ tahun memiliki luaran lebih buruk karena perubahan pada mielum berupa berkurangnya $\gamma$-motor neurons, sinaps dan dendrit mielum, sel kornu anterior, serta serabut mielin traktus kortikospinal dan funikulus posterior. Selain itu, usia tua sering disertai komorbid penyakit lain yang dapat mengganggu proses penyembuhan, intraoperasi atau bahkan saat pengisian form skor fungsional. ${ }^{10}$

Kaitan onset penyakit sebagai faktor prognosis didasari teori bahwa semakin lama onset penyakit, maka kompresi mekanik terhadap mielum akan semakin berat, menyebabkan iskemia, kerusakan sawar darah mielum, inflamasi, kavitasi, dan degenarasi akson dan adanya kemungkinan cedera reperfusi akibat restorasi aliran darah jaringan setelah kondisi iskemik lama. Namun pada penelitian ini baik usia dan onset tidak memiliki hubungan bermakna dengan luaran CSM pascaoperasi. Hal ini dimungkinkan karena jumlah sampel usia $>65$ tahun yang sangat sedikit dan mayoritas subjek datang dengan onset gejala $\leq 1$ tahun. ${ }^{3,8-9}$

Skor fungsional preoperasi juga dianggap memengaruhi luaran pascaoperasi. Menurut Holly $\mathrm{dkk}$, skor Nurick preoperatif berhubungan signifikan dengan skor Nurick pascaoperasi pada follow up 18156 bulan, sehingga pasien dengan skor preoperasi tinggi akan memiliki prognosis lebih buruk. Namun penelitian ini tidak mendapatkan hubungan yang bermakna antara skor fungsional Nurick preoperasi terhadap skor 1 tahun pascaoperasi. Perbedaan hasil yang didapat dari penelitian yang ada mungkin disebabkan karena cakupan skor fungsional Nurick dalam menentukan berat ringan penyakit berdasarkan perbaikan ekstremitas bawah, sehingga perbaikan gejala pascaoperasi pada ekstremitas atas tidak terpantau. Perbedaan lainnya yaitu populasi penelitian ini kecil dan dalam jangka waktu follow up yang lebih singkat, dari sumber pembahasan penelitian sebelumnya, digunakan rerata follow up hingga 5 tahun. ${ }^{9}$ 
Tabel 2. Hubungan Perbaikan Skor Fungsional Nurick dengan Karakteristik Subjek $(\mathbf{n}=\mathbf{5 0})$

\begin{tabular}{|c|c|c|c|}
\hline \multirow{2}{*}{ Variabel } & \multicolumn{2}{|c|}{ Perbaikan Skor Nurick } & \multirow{2}{*}{ p* } \\
\hline & Tidak & Ya & \\
\hline \multicolumn{4}{|l|}{ Usia } \\
\hline - $>65$ & $6(100 \%)$ & $41(93,2 \%)$ & $>0,999$ \\
\hline - $\leq 65$ & $0(0 \%)$ & $3(6,8 \%)$ & \\
\hline \multicolumn{4}{|l|}{ Jenis kelamin } \\
\hline - Laki-laki & $5(83,3 \%)$ & $33(75 \%)$ & $>0,999$ \\
\hline - Perempuan & $1(16,7 \%)$ & $11(25 \%)$ & \\
\hline \multicolumn{4}{|l|}{ Nurick preoperasi } \\
\hline - $\leq 2$ & $2(33,3 \%)$ & $29(65,9 \%)$ & 0,184 \\
\hline - $>2$ & $4(66,7 \%)$ & $15(34,1 \%)$ & \\
\hline \multicolumn{4}{|c|}{ Jarak antara onset dengan waktu operasi } \\
\hline - $\leq 1$ tahun & $5(83,3 \%)$ & $35(79,5 \%)$ & $>0,999$ \\
\hline - $>1$ tahun & $1(16,7 \%)$ & $9(20,5 \%)$ & \\
\hline \multicolumn{4}{|c|}{ Hipointensitas pada MRI T1WI } \\
\hline - Ada & $3(50 \%)$ & $2(4,5 \%)$ & 0,009 \\
\hline - Tidak ada & $3(50 \%)$ & $42(95,5 \%)$ & \\
\hline \multicolumn{4}{|c|}{ Hiperintensitas pada MRI T2WI } \\
\hline - Ada & $3(50 \%)$ & $17(38,6 \%)$ & 0,672 \\
\hline - Tidak ada & $3(50 \%)$ & $27(61,4 \%)$ & \\
\hline \multicolumn{4}{|l|}{ Jenis operasi } \\
\hline - Anterior & $3(50 \%)$ & $35(79,5 \%)$ & 0,141 \\
\hline - Posterior & $3(50 \%)$ & $9(20,5)$ & \\
\hline
\end{tabular}

*Uji Fisher; MRI: magnetic resonance imaging; T1WI: T1-weighted images; T2WI: T2-weighted images.

Pemilihan tindakan bedah pada kasus CSM hingga saat ini masih kontroversial. Dasar pemilihan antara lain adalah lokasi mielum yang terkompresi, instabilitas, kemungkinan pseudoartrosis, sagital alignment, serta jumlah level yang terlibat. Zhu dkk mengemukakan prosedur anterior memiliki luaran pascaoperasi yang lebih baik dibandingkan posterior, terutama pada kasus multilevel CSM. Berbeda dengan hasil penelitian ini, tidak terdapat hubungan yang signifikan antara jenis operasi dengan luaran skor fungsional. Kemungkinan keterbatasan dalam penelitian ini adalah adanya faktor eksternal yang menentukan pemilihan jenis tindakan di luar kaitan dengan prognosis pasien (surgeon preference). ${ }^{11}$

Tetreault dkk mengatakan bahwa berdasarkan konsensus AOSpine, gambaran mielum pada sekuens T2WI yang hiperintens merupakan faktor signifikan sebagai penentu prognosis pascaoperasi dekompresi kanal spinal pada pasien CSM. Studi lain menemukan bahwa hiperintensitas mielum pada sekuens T2WI bukan merupakan faktor prognostik yang bermakna, karena hanya merupakan perubahan mielum yang reversibel (edema dan gliosis). Di sisi lain, hipointensitas pada MRI T1WI sugestif terhadap proses kronik, ireversibel, nekrosis, serta formasi syrinx atau cavitasi, yang dapat dikaitkan dengan luaran pascaoperasi yang lebih buruk..$^{10,12-13}$

Temuan hiperintens pada sekuens T2WI dapat dijadikan penanda diagnosis. Nouri dkk mengungkapkan bahwa prevalensi terjadinya hiperintens pada T2WI berkisar 58\%-85\%, dengan angka temuan insidental (tanpa gejala) sekitar 2,3\%. Sementara temuan hipointensitas T1WI merupakan penanda yang spesifik untuk memperkirakan defisit neurologis awal serta prognosis pascaoperasi. ${ }^{13}$ Pada analisis hiperintensitas sekuens T2WI dengan uji 
Fisher, tidak didapatkan hubungan yang bermakna antara gambaran tersebut terhadap skor fungsional Nurick. Pada analisis hipointensitas mielum pada sekuens T1WI, didapatkan jumlah yang lebih sedikit dibanding hiperintens pada T2WI, yaitu hanya $10 \%$ subjek.

Pada penelitian ini, semua subjek dengan gambaran hipointensitas T1WI juga didapati hiperintensitas pada T2WI. Hal tersebut sejalan dengan Nouri dkk, bahwa semua gambaran hipointens pada T1WI akan memberikan gambaran hiperintens pada T2WI. Hal ini disebabkan setiap peningkatan tissue relaxation (TR) lebih sensitif pada sekuens T2WI, sehingga lebih dahulu memberikan gambaran hiperintens pada sekuens T2WI jika dibandingkan dengan hipointens pada T1WI. Oleh karena itu, temuan hiperintens pada T2WI bisa disertai gambaran normal mielum pada T1WI, sedangkan temuan hipointens mielum pada T1WI pasti disertai adanya hiperintensitas mielum pada T2WI.

Pada penelitian ini didapatkan hubungan yang bermakna antara hipointensitas mielum pada T1WI terhadap luaran skor fungsional pasien CSM 1 tahun pascaoperasi. Sesuai dengan teori adanya temuan hipointensitas pada MRI T1WI sugestif terhadap proses kronik, ireversibel (nekrosis, formasi syrinx atau cavitasi), yang dapat dikaitkan dengan luaran yang lebih buruk pascaoperasi. Mielum yang telah mengalami kerusakan yang irreversibel, kemampuan regenerasi sistem saraf menjadi terbatas, meskipun telah dilakukan dekompresi. Hal ini menyebabkan buruknya luaran pascaoperasi pada subjek dengan gambaran hipointensitas mielum preoperasi. ${ }^{14}$

Perbedaan hasil temuan hiperintensitas pada T2WI sebagai faktor prognosis dapat disebabkan sampel pada penelitian lain memiliki karakteristik jarak onset dengan waktu operasi yang lebih dari 1 tahun, sehingga kerusakan mielum sudah berat, sedangkan $80 \%$ subjek penelitian ini memiliki jarak onset dengan waktu operasi dibawah 1 tahun, sehingga kerusakan pada mielum belum berat. Pembedahan dekompresi kanal servikal diharapkan dapat memperbaiki sirkulasi aliran darah mielum, mengurangi edema, dan merangsang regenerasi serabut saraf yang tertekan akibat kompresi mekanik, sehingga serangkaian perbaikan ini diharapkan dapat memperbaiki gambaran intensitas mielum pada pemeriksaan MRI.

\section{KESIMPULAN}

Adanya gambaran hipointensitas mielum pada MRI servikal T1WI merupakan faktor prognostik buruk terhadap luaran pascaoperasi pada pasien CSM.

\section{DAFTAR PUSTAKA}

1. Sanford E. Cervical spondylotic myelopathy: diagnosis and treatment. J Am Acad Orthop Surg. 2001;9(6):37688.

2. Lebl D, Hughes A, Cammisa F, O'Leary P. Cervical spondylotic myelopathy: pathophysiology, clinical presentation, and treatment. HSS J. 2011;7(2):170-8.

3. Tetreault L, Karpova A, Fehlings M. Predictors of outcome in patients with degenerative cervical spondylotic myelopathy undergoing surgical treatment: results of a systematic review. Eur Spine J. 2013;24(S2):236-51.

4. Aggarwal R, Srivastava S, Bhosale S, Nemade P. Prediction of surgical outcome in compressive cervical myelopathy: a novel clinicoradiological prognostic score. J Craniovertebr Junction Spine. 2016;7(2):82-6.

5. Kong L, Meng L, Wang L, Shen Y, Wang P, Shang Z. Evaluation of conservative treatment and timing of surgical intervention for mild forms of cervical spondylotic myelopathy. Exp Ther Med. 2013;6(3):852-6.

6. Kumar P. Clinico-radiological correlation in a cohort of cervical myelopathy patients. J Clin Diagn Res. 2015;9(1):TC01-7.

7. Zhang C. Application of magnetic resonance imaging in cervical spondylotic myelopathy. World J Radiol. 2014;6(10):826-32.

8. Holly LT, Matz PG, Anderson PA, Groff MW, Heary RF, Kaiser MG, dkk. Clinical prognostic indicators of surgical outcome in cervical spondylotic myelopathy. J Neurosurg Spine. 2009;11(2):112-8.

9. Wu JC, Ko CC, Yen YS, Huang WC, Chen YC, Liu L, dkk. Epidemiology of cervical spondylotic myelopathy and its risk of causing spinal cord injury: a national cohort study. Neurosurg Focus. 2013;35(1):E10.

10. Tetreault L, Nouri A, Singh A, Faweett M, Fehlings M. Predictors of outcome in patients with cervical spondylotic myelopathy undergoing surgical treatment: a survey of members from AOSpine international. World Neurosurg. 2014;81(3):623-33.

11. Zhu B, Xu Y, Liu X, Liu Z, Dang G. Anterior approach versus posterior approach for the treatment of multilevel cervical spondylotic myelopathy: a systemic review and meta-analysis. Eur Spine J. 2013;22(7):1583-93. 
12. Liu F, Sun Y, Shen Y, Ding W, Wang L. Prognostic value of magnetic resonance imaging combined with electromyography in the surgical management of cervical spondylotic myelopathy. Exp Ther Med. 2013;5(4):1214-8.

13. Kalsi-Ryan S, Singh A, Massicotte E, Arnold P, Norvell D. Ancillary outcome measures for assessment of individuals with cervical spondylotic myelopathy. Spine. 2013;38(225):5111-22.

14. Nouri A, Martin AR, Mikulis D, Fehlings MG. Magnetic resonance imaging assessment of degenerative cervical myelopathy: a review of structural changes and measurement techniques. Neurosurg Focus. 2016;40(6):E5. 